\title{
STUDIES OF BLOOD GLYCOLYSIS
}

\section{Sugar and Phosphorus Relationships during Glycolysis in NORMal BLOOD ${ }^{1}$}

\section{By GEORGE MARTIN GUEST}

(From the Infants' and Children's Hospital and the Department of Pediatrics, Harvard Medical School; and the Children's Hospital Research Foundation and the Department of Pediatrics, College of Medicine, University of Cincinnati)

(Received for publication January 23, 1932)

The series of experiments presented in this paper demonstrate certain relationships in the progressive changes of sugar and phosphorus observed in defibrinated blood incubated in vitro at $37^{\circ} \mathrm{C}$. through periods of from ten to twenty-four hours. The accompanying figures illustrate a pattern of these changes which may be regarded as characteristic of normal bloods and bloods of normal animals rendered hyperglycemic and hypoglycemic. Similar studies of glycolysis and phosphorus relationships observed in blood samples from children with a variety of diseases will be presented in the succeeding paper.

Most of the evidence that phosphorus plays an essential rôle in the intermediary carbohydrate metabolism of the animal body is based upon observations of shifts of phosphorus in the body and fluctuations in the excretion of phosphorus which accompany the storage and burning of sugar. This subject has been recently reviewed by Peters and Van Slyke (1931). It is generally believed that there is formation of carbohydrate-phosphoric acid compounds at certain stages in the processes of storage (as in the synthesis of glycogen) and burning of sugar, but the actual isolation of such compounds from animal tissues has proved difficult and the evidence that such compounds exist in the animal body is for the most part indirect. Goodwin and Robison (1924) reported the isolation of two phosphoric esters from the blood; one of these esters reduced Fehling's solution. The existence of hexose-phosphoric acid compounds in yeasts was demonstrated by Harden and his collaborators (1905-1923), Robison (1922), Levene and Raymond $(1928,1929)$, and the rôle of phosphorus in alcoholic fermentation of sugar by yeasts was clearly defined by Harden's studies (1923). The manner in which phosphorus enters into the splitting of sugar by yeast enzymes is better understood than are the processes by which sugar is utilized in the animal body, but certain steps of the chemical mechanisms in the respective organisms are probably closely analogous and much that has been learned from the one has been profitably applied by a number of investigators in studying the other.

The earliest suggestion that phosphorus might be concerned in blood glycolysis appears to have been made by Rona and Döblin (1911), who seized

1 An abstract of this paper was read at a meeting of the American Pediatric Society, Montreal, June 18, 1930. 
upon the observations of Löb (1911) that sodium phosphate when added to an alkaline solution of glucose hastened the spontaneous destruction of the glucose. Interrelationships between phosphorus and sugar in the blood during glycolysis have been demonstrated in a number of investigations reported by Rona and his collaborators (1911-1927), Bierry and Moquet (1924, 1925), Lawaczeck (1924), Martland (1925), Martland, Hansman and Robison (1924), Jost (1927), Engelhardt and Braunstein (1928), Barrenscheen and Hubner (1930), Engelhardt and Ljubimowa (1930) and Roche and Roche (1927, 1929). Briefly summarized, these investigations have demonstrated the following points:

When freshly drawn blood is defibrinated and incubated, the blood sugar progressively diminishes. During the first few hours the inorganic phosphorus may diminish slightly or may remain at a stationary level. When glycolysis slows, or stops, from lack of sugar, there is a rapid liberation of inorganic phosphorus from the organic phosphorus compounds of the cells. There is general concurrence in the explanation, as stated by Engelhardt and Braunstein (1928) and by Roche and Roche (1929), that during blood glycolysis two main reactions are going on: namely, synthesis of hexose-phosphoric acid esters as a first step in glycolysis, and the hydrolysis of these esters. These reactions are interrelated, but the hydrolysis may proceed independent of synthesis. According to the speed of the two reactions there is observed: 1, excess of synthesis over hydrolysis, with fixation of the inorganic phosphorus in organic form; 2 , equality of the two reactions; 3 , excess of hydrolysis over synthesis, resulting in liberation of inorganic phosphorus.

The processes of glycolysis, ester-synthesis and ester-hydrolysis are affected differently by various changes in the state of the blood. Most of the glycolysis is due to the erythrocytes and is probably intracellular; hence, apart from the chemical state of the blood, the number of cells in a given sample is an important factor in glycolysis (Katayama (1926), Kawashima (1923), Barer (1931)). No glycolysis takes place in the plasma or serum if precautions are taken to avoid damage to the cells and the escape of their contents into the serum during its preparation (Rona and Döblin (1911), Milne and Peters (1912), Kawashima (1923)). Hemolysis of the blood with water stops glycolysis (Doyon and Morel (1903), Rona and Döblin (1911)) and ester synthesis, but does not stop phosphoric-ester hydrolysis (Martland, Hansman and Robison (1924), Lawaczeck (1924)). Dilution of blood with isotonic salt solution merely slows glycolysis. Dilution of the cells with serum or a phosphate mixture gives greater glycolysis than equal dilution of the cells with $\mathrm{NaCl}$ or Ringer's solution (Kawashima (1924)). The addition of glucose and phosphate in an appropriately buffered mixture to the whole blood gives greater synthesis of esters and increased speed of glycolysis (Roche and Roche (1929)). The optimum reaction for glycolysis is around $\mathrm{pH} \mathrm{7.8-approximately} \mathrm{the} \mathrm{optimum} \mathrm{for} \mathrm{ester}$ synthesis. According to Martland (1925) and Rona and Iwasaki (1927), ester synthesis and glycolysis take place only at an alkaline reaction, and are slowed by a shift to below pH 7.3. Ester hydrolysis occurs over a greater range than glycolysis, from $\mathrm{pH} 6.0$ to 9.0 , but in the absence of sugar, hydrolysis is most rapid at around pH 8.0 (Rona and Iwasaki (1927)).

Discussion of the nature and distribution of the various phosphorus compounds in blood may be found in the papers of Kay and Byrom (1927) and in the recent review by Peters and Van Slyke (1931). Studies of the phosphorus distribution in the blood of dogs have been reported in this journal by Guest and Andrus (1932). In normal blood the inorganic $P$ has a slightly lower concentration in the cells than in the plasma, while the organic acid- 
soluble $P$ (the fraction designated "Ester- $P$ " by Kay and Byrom) is practically confined to the cells, there being usually less than $0.5 \mathrm{mgm}$. per cent present in the plasma.

\section{METHODS}

Blood samples were defibrinated with a glass rod or a wooden stick and incubated at $37^{\circ} \mathrm{C}$. in an Erlenmeyer flask with a rubber stopper. At the intervals indicated, 1.0 or $2.0 \mathrm{cc}$. samples were removed for sugar and phosphorus determinations, and the changing values thus determined are shown graphically in the figures.

Sugar determinations were made using the Folin-Wu (1919) copper solution and the molybdate solution modified by Folin (1926). Phosphorus determinations were made by the Fiske-Subbarow method (1925).

Precautions to maintain sterility were not taken after suitable controls had indicated that slight bacterial contamination did not alter the cycle of chemical changes dealt with here. Mackenzie (1915), Katayama (1926) and Falcon-Lesses (1927) found that slight bacterial contamination did not affect the glycolytic rate.

\section{RESULTS}

Glycolysis and changes of phosphorus in normal blood. (Figures 1 and 2)

Glycolysis usually occurs in normal blood at a uniform rate of from 13 to $16 \mathrm{mgm}$. per cent loss of sugar per hour, continuing until there remains a residual reducing substance equivalent to about $20 \mathrm{mgm}$. per cent of sugar. See Figure 1. Sometimes the rate is slightly faster during the first hour, and it may slow considerably during the last hour or two. The residual substance apparently corresponds to the unidentified reducing substance of the blood which is not fermented by yeast (Hiller, Linder and Van Slyke (1925), Folin and Svedberg (1926)). When determined by different methods this substance gives considerably different values; Falcon-Lesses (1927) using Folin's (1926) copper solution for sugar determination found 6 to $8 \mathrm{mgm}$. per cent of non-glycolyzing reducing substance in blood. Whatever method of sugar determination is used, however, the relative changes which determine the rate of glycolysis are the same. During the first few hours the inorganic phosphorus either remains at a constant level or diminishes slightly. At the end of about 6 hours, when the sugar is exhausted the inorganic phosphorus rises sharply and progressively to reach finally a concentration of 20 to $25 \mathrm{mgm}$. per cent at about the 20th hour, after which time it changes very little.

The source of the inorganic phosphorus which is found increasing rapidly after the 6th hour of incubation (as in Fig. 1) is demonstrated by the more complete analyses of the succeeding experiment. In the experiment shown in Figure 2, $150 \mathrm{cc}$. of blood from a normal man were defi- 
brinated and incubated as usual. Values for the sugar content and the distribution of phosphorus in the blood as the inorganic P, total acidsoluble $P$ and total $P$, were determined at the intervals indicated in Figure 2 over a period of 22 hours. Glycolysis in this blood averaged $13.5 \mathrm{mgm}$. per cent loss of sugar per hour and was complete at about the 6th hour. The inorganic $P$ diminished slightly during the first 3 hours and rose sharply after the 6th hour, this rise starting just before glycolysis was completed. The total $\mathbf{P}$ and the acid soluble $\mathbf{P}$ were unchanged during the 22 hours; it appears therefore that the acid-insoluble $P$ (the difference between these two values) is not affected during this period of incubation.

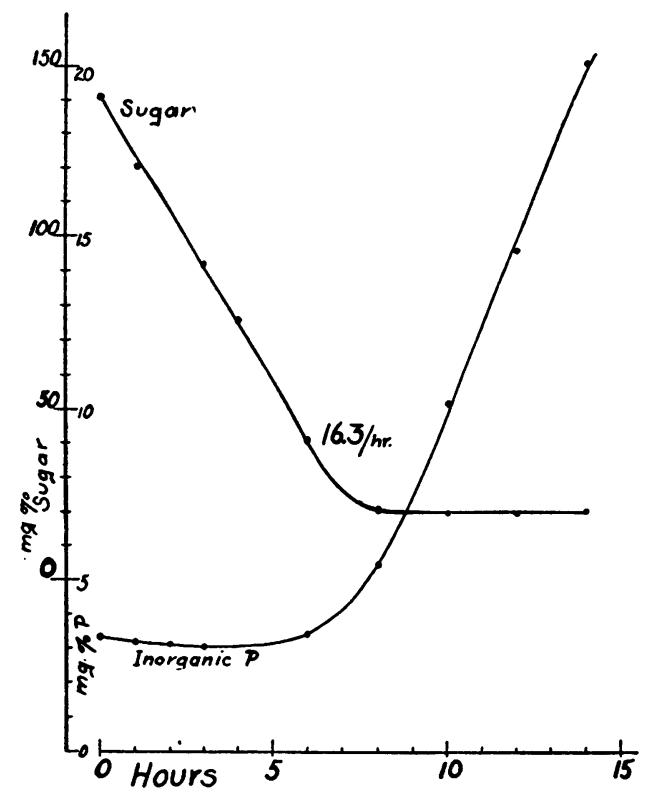

Fig. 1. Glycolysis and Changes of Inorganic Phosphorus in Normal Human Blood, Defibrinated and Incubated at $37^{\circ} \mathrm{C}$.

The values for the organic acid-soluble $P$ ("ester-phosphorus"), represented in the figure by the dotted curve, were obtained by subtracting the inorganic $\mathbf{P}$ values from those of the total acid-soluble $P$, and it may be seen from these changing values that the increase of the inorganic $P$ after the 6th hour is at the expense of the organic acid-soluble "esterphosphorus." Parallel measurements made on the serum showed that the inorganic $\mathrm{P}$ escaped from the cells as rapidly as it was liberated from the organic compounds, but for the sake of brevity this phase of the problem is omitted from the present discussion.

According to theories advanced by the authors cited in the introduction the order of events visualized in these two figures is probably as 
follows. Through enzyme synthesis, free sugar is combined with free inorganic phosphate to form hexose-phosphoric acid esters in the cells. As the glycolytic enzyme (or enzymes) splits the sugar molecule (first to

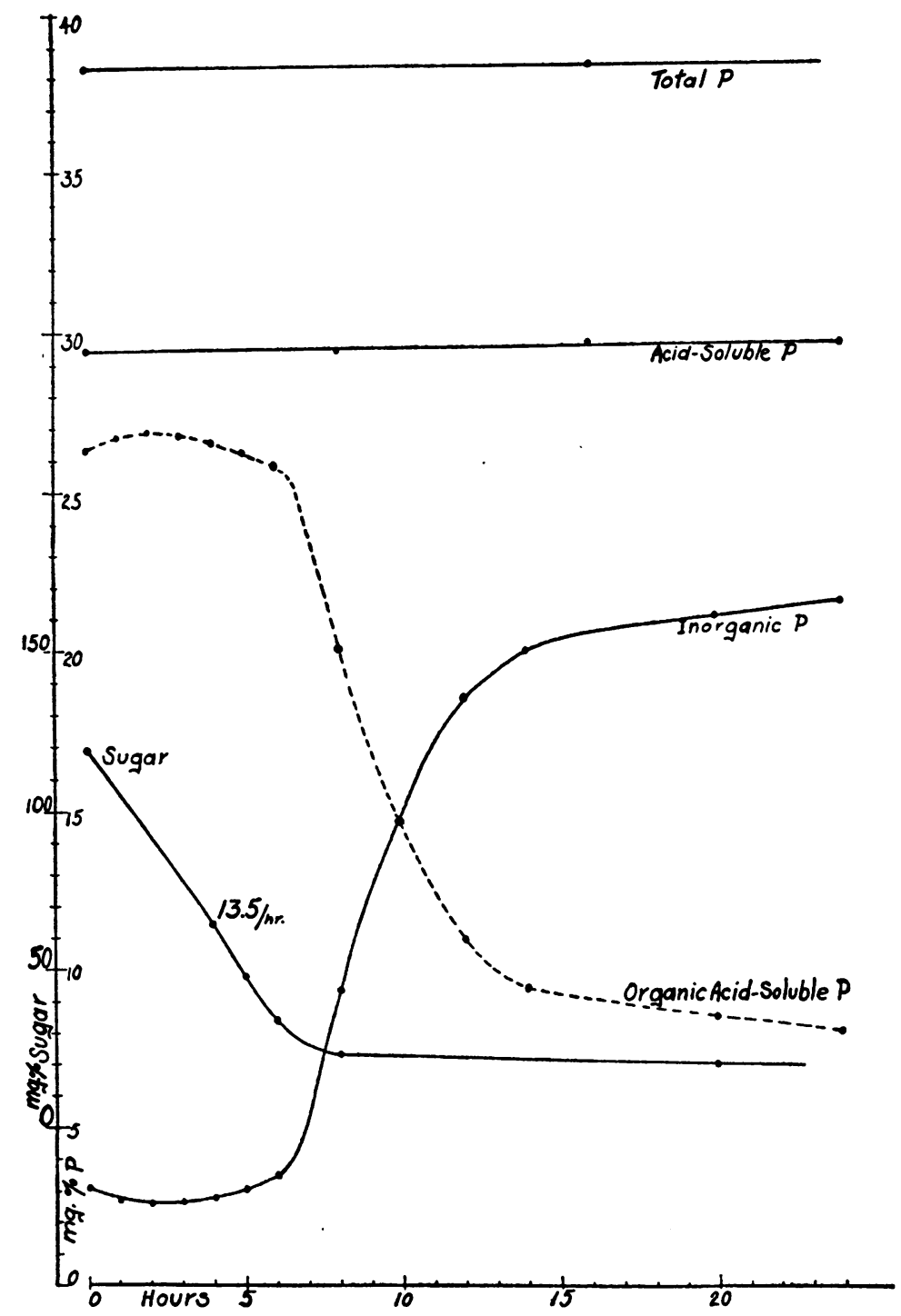

Fig. 2. Changes in Phosphorus Partition During Glycolysis in Normal Human Blood, Defibrinated and Incubated at $37^{\circ} \mathrm{C}$.

two molecules of lactic acid) the phosphate is liberated to combine again with sugar. Synthesis and hydrolysis in the blood are at first about equal, and while sugar is present the concentration of inorganic $P$ changes 
very little. When the sugar is exhausted, the inorganic $P$ increases rapidly because of the continuous hydrolysis of the esters with no sugar available for their resynthesis.

That the concentration of sugar in the blood has an important bearing upon the time relationships of the changes thus observed is demonstrated in the following experiments in which the sugar content of different bloods was changed by the addition of sugar to the blood in vitro, and by the administration of insulin to diminish the sugar content of the blood in vivo.

The effect of changes in the sugar content of normal blood upon the order of changes of inorganic phosphorus during glycolysis. (Figures 3 to 8 , inclusive)

Levulose was used in the experiments that follow because this sugar gave somewhat more clear cut results than did glucose. There are, however, only slight differences between the behavior of glucose and levulose in such experiments as these.

In the experiment shown in Figure 3,100 cc. of blood from a normal man were defibrinated and incubated as usual. Sugar and inorganic $P$ determinations were made at the intervals indicated by the graphs $\left(S_{1}\right.$ and $\left.P_{1}\right)$. At the 5th hour the blood was divided, and $30 \mathrm{cc}$. transferred to each of two flasks; to one was added $1.0 \mathrm{cc}$. of 6.0 per cent (approximate) levulose in 0.85 per cent $\mathrm{NaCl}$ solution, sufficient to elevate the total sugar content in this blood from $36 \mathrm{mgm}$. per cent to $234 \mathrm{mgm}$. per cent as shown $\left(\mathrm{S}_{2}\right)$; the other flask received an equal amount of 0.85 per cent $\mathrm{NaCl}$ solution. Glycolysis of the added levulose $\left(\mathrm{S}_{2}\right)$ went on at practically the same rate as that at which the original blood sugar $\left(S_{1}\right)$ had disappeared, and the inorganic phosphorus $\left(\mathrm{P}_{2}\right)$ in this blood continued to diminish slowly up to the 11 th hour when the experiment was discontinued. In the blood sample to which no sugar was added, the inorganic phosphorus $\left(\mathrm{P}_{1}\right)$ rose sharply as soon as glycolysis was completed.

The above experiment was repeated, using a larger sample of blood in order to continue the measurements over a longer period of time. The blood was defibrinated and incubated as usual and determinations of the sugar and inorganic $P$ content were made at the intervals indicated in Figure 4. At the 5th and 15th hours, 20 cc. of blood were removed from the original flask to smaller flasks and levulose added to these flasks in sufficient quantity to raise the sugar content of the blood in each to the levels indicated by $\mathrm{S}_{2}$ and $\mathrm{S}_{3}$. Glycolysis of the added sugar proceeded at nearly equal rates in each case. In the untreated blood the inorganic $P$ rose after the 6 th hour, at which time the glycolysis was becoming considerably slower $\left(S_{1}\right)$. In the blood with added sugar $\left(S_{2}\right)$ the inorganic phosphorus $\left(\mathrm{P}_{2}\right)$ remained low and was rising only slowly 
from the 18th to the 20th hour. At the 15th hour the inorganic phosphorus $\left(\mathrm{P}_{1}\right)$ in the untreated blood was above $17.5 \mathrm{mgm}$. per cent and increased to $19.7 \mathrm{mgm}$. per cent at the 22nd hour. Following the addition of levulose to the blood at the 15th hour, glycolysis proceeded at a regular rate $\left(\mathrm{S}_{3}\right)$ and the inorganic phosphorus $\left(\mathrm{P}_{2}\right)$ in this blood diminished to $15.5 \mathrm{mgm}$. per cent at the 22nd hour when the experiment was discontinued.

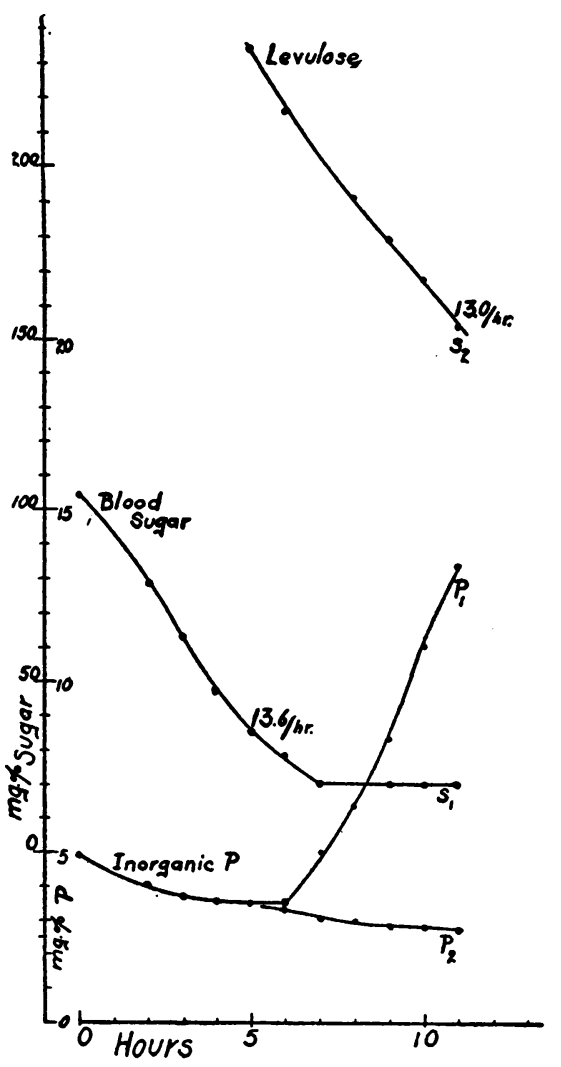

Fig. 3. Levulose Added to Defibrinated Human Blood at the 5Th Hour OF INCUBATION.

From these two experiments one may conclude that in normal blood an excess of sugar, added in order to prolong the period of glycolysis, delays the rise of the inorganic phosphorus. The fact that the addition of sugar to the blood at the 15th hour caused the inorganic phosphorus to diminish, instead of further increasing, indicates that the enzymes were active and capable of ester-synthesis long after the glycolysis of the original blood sugar was finished, and after ester-hydrolysis had increased the inorganic phosphorus to a high level. 
The curves $S_{1}$ and $P_{1}$ in Figure 5 illustrate the time relationships between changes in sugar and inorganic phosphorus which were observed during glycolysis in the blood of a normal rabbit. Another rabbit was given 20 units of insulin to provoke a hypoglycemia, and a blood sample was taken when the rabbit was having mild convulsions. The curves

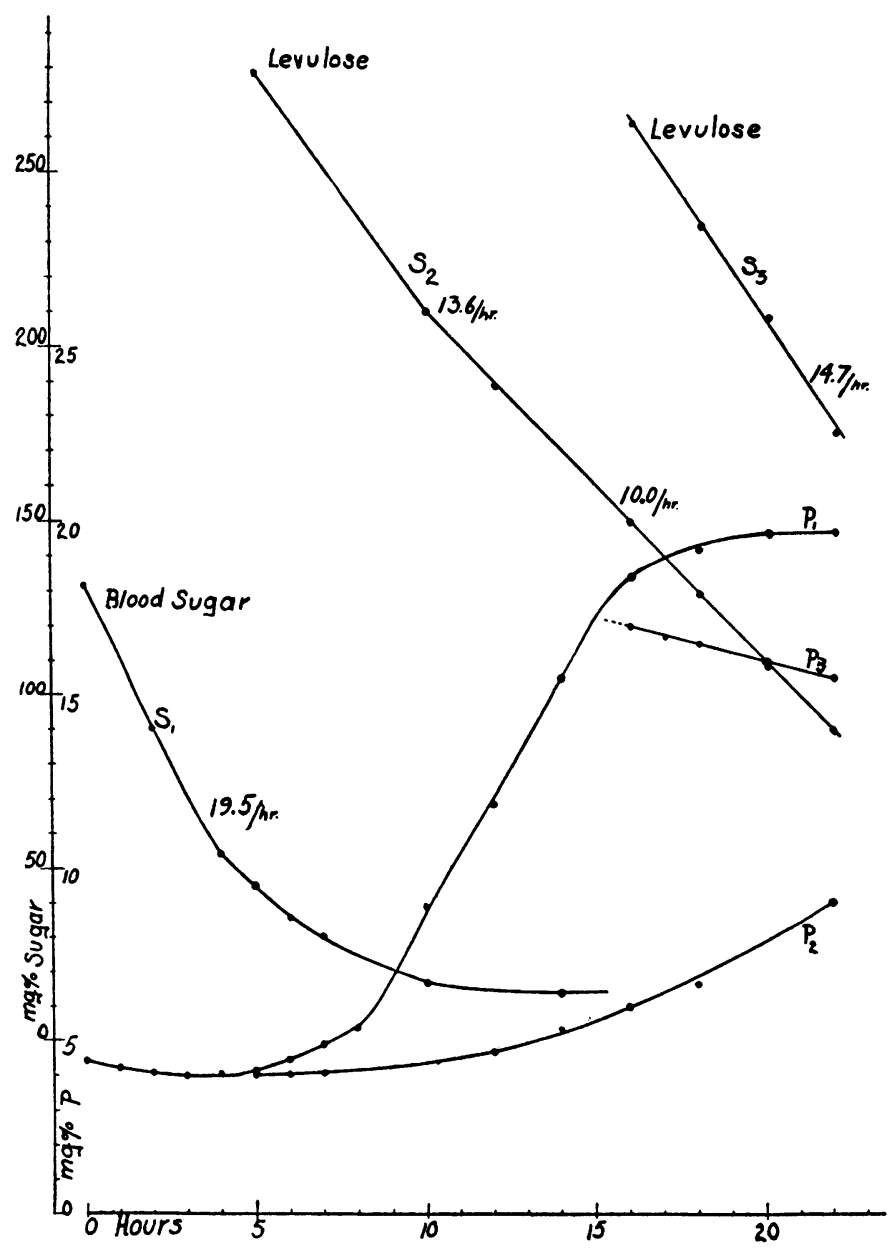

Fig. 4. Levulose Added to Defibrinated Human Blood at the 5Th AND 15Th Hours OF InCUBation.

$\mathrm{S}_{2}$ and $\mathrm{P}_{2}$ represent glycolysis and ester-phosphorus hydrolysis observed in this blood. The initial effect of insulin in animals is a depression of the inorganic phosphorus of the blood (Wigglesworth, Woodrow, Smith and Winter (1923), Harrop and Benedict (1924)), but Briggs, Koechig, Doisy and Weber (1923) observed that in the stage of marked hypoglycemia and irritability (convulsions) the inorganic phosphorus tended to 
rise again above its original level. The changes illustrated by the curve $\mathrm{P}_{2}$ in the figure offer an explanation for the findings of these authors. Even in vivo, if the blood sugar is thus reduced by insulin, ester-phosphorus hydrolysis probably leads to an increase of the inorganic phosphorus of the blood when there is a lack of sugar available for resynthesis of the esters.

In order to show definitely that the rapid ester-phosphorus hydrolysis observed in this hypoglycemic blood was in fact due to the lack of sugar

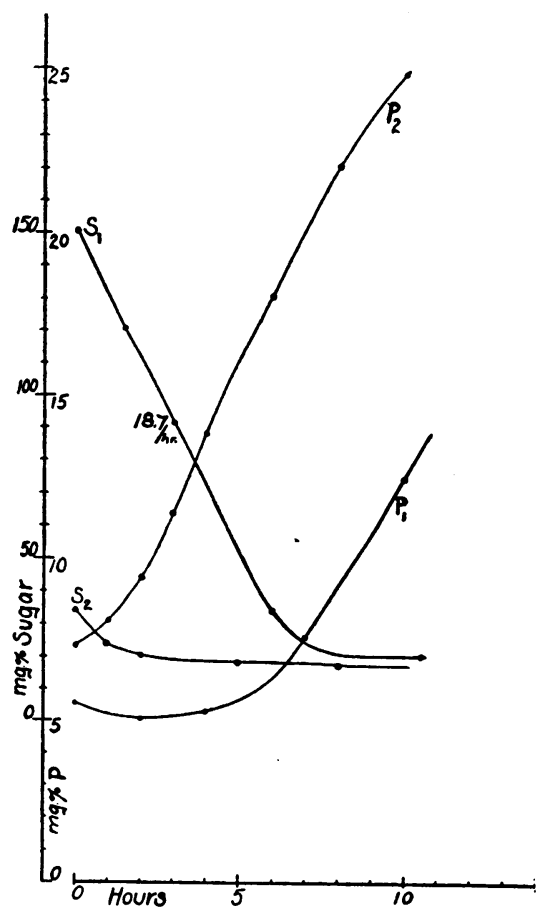

Fig. 5. Glycolysis and Changes of Inorganic Phosphorus in Defibrinated Normal Rabbit's Blood ( $S_{1}$ and $P_{1}$ ), aNd in the Blood of a RABBit RENDERED HyPOGLYCEMIC BY INSULIN $\left(\mathrm{S}_{2}\right.$ AND $\left.\mathrm{P}_{2}\right)$.

rather than to some effect attendant upon the insulin injection, sugar was added in vitro to another sample of rabbit's blood that had been rendered hypoglycemic in the same fashion; the result of this experiment is shown in Figure 6. Twenty units of insulin given in divided doses to a rabbit reduced the blood sugar content from $147 \mathrm{mgm}$. per cent to $24 \mathrm{mgm}$. per cent. The animal was having mild convulsions when a sample of blood was drawn from the heart. The blood sample $(40 \mathrm{cc}$.) was defibrinated and divided into two flasks; to one flask was added $0.5 \mathrm{cc}$. of 10 per cent (approximate) levulose solution. The flasks were incubated as usual 
and sugar and inorganic phosphorus determinations were made at the intervals indicated in Figure 6. In the blood in which the sugar content was only $24 \mathrm{mgm}$. per cent, glycolysis was rapidly completed $\left(\mathrm{S}_{1}\right)$ and the inorganic $P\left(P_{1}\right)$ rose from the start of incubation; in the blood to which levulose was added glycolysis occurred at a regular rate $\left(S_{2}\right)$ and the inorganic phosphorus $\left(\mathrm{P}_{2}\right)$, after a slight initial rise, remained low and was increasing only slowly after the 11 th hour.

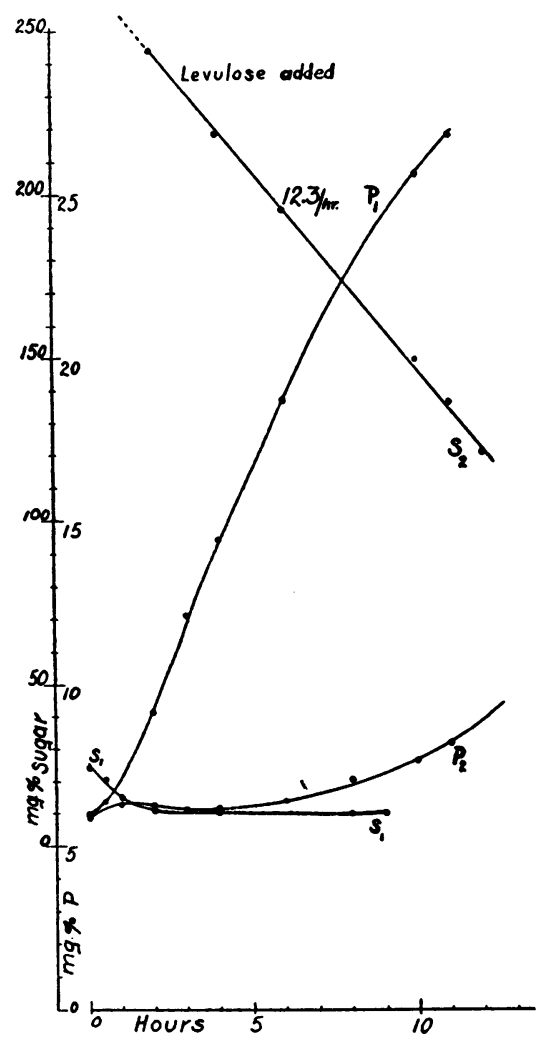

Fig. 6. Changes of Sugar and Inorganic Phosphorus in the Blood OF a RabBit ReNDEREd HypoglyCEMIC BY INSULIN ( $S_{1}$ AND $P_{1}$ ), AND IN the Same Blood with Levulose Added $\left(\mathrm{S}_{2}\right.$ and $\left.\mathrm{P}_{2}\right)$.

In Figures 7 and 8 are shown curves representing glycolysis and changes of inorganic phosphorus in blood samples taken from two diabetic patients, one with high and the other with low blood sugar content. Both patients had been receiving insulin and were under good dietary control and appeared to be in a healthy state when these blood samples were taken. In the first patient mild hyperglycemia was allowed to develop by withholding insulin; there was marked glycosuria at the time the 
blood sample was taken, but no acetone appeared in the urine. The blood sample taken at this time, with sugar content $292 \mathrm{mgm}$. per cent, was defibrinated and incubated as usual; determinations of the sugar and inorganic phosphorus made at intervals during a period of 18 hours gave the results shown in Figure 7. From the second patient a blood sample was taken after a dose of insulin had been given to induce a mild hypo-

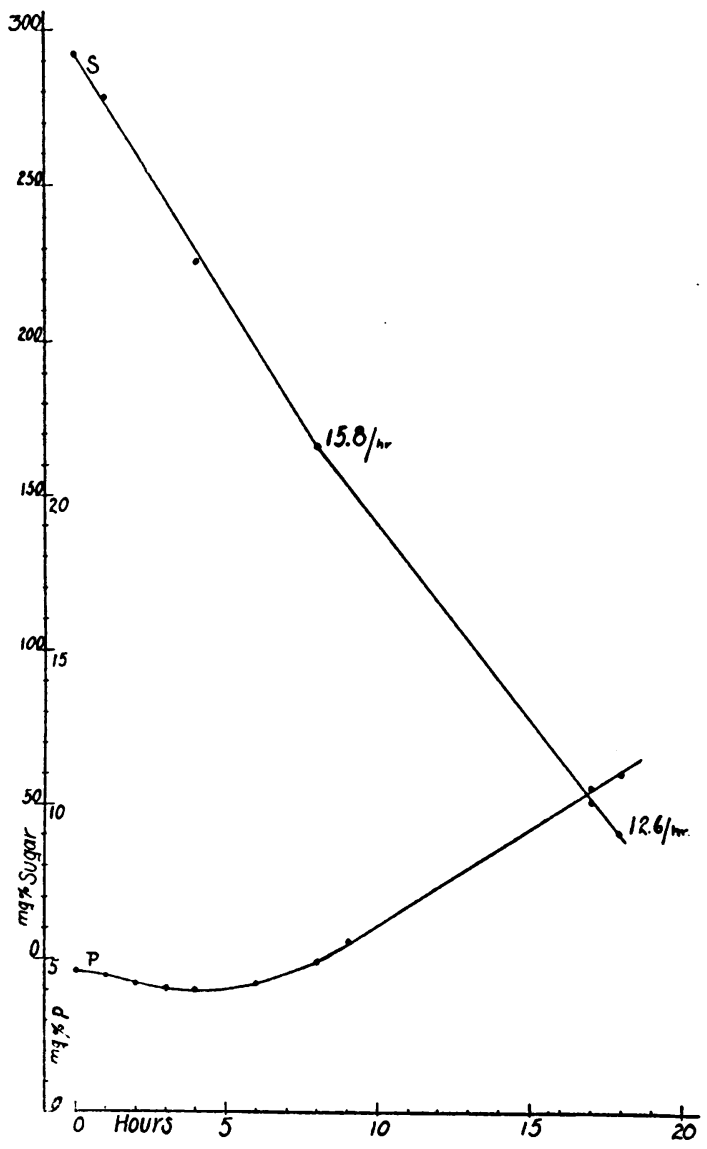

Fig. 7. Glycolysis and Changes of Inorganic Phosphorus in the Hyperglycemic Blood of a Diabetic MaN.

glycemia. This blood sample, with sugar content $65 \mathrm{mgm}$. per cent, was defibrinated and divided into two flasks (10 cc. in each), to one of which was added $0.2 \mathrm{cc}$. of 10 per cent levulose, sufficient to elevate the blood sugar to $260 \mathrm{mgm}$. per cent as shown by $S_{2}$ in Figure 8 . Glycolysis occurred at practically the same rate in both samples $\left(S_{1}\right.$ and $\left.S_{2}\right)$. With the completion of glycolysis in the sample to which no sugar was added, the inorganic phosphorus $\left(P_{1}\right)$ rose sharply after the second hour, while 
in the blood to which levulose was added the inorganic phosphorus $\left(\mathrm{P}_{2}\right)$ was progressively diminishing through the 6th hour when the experiment was discontinued.

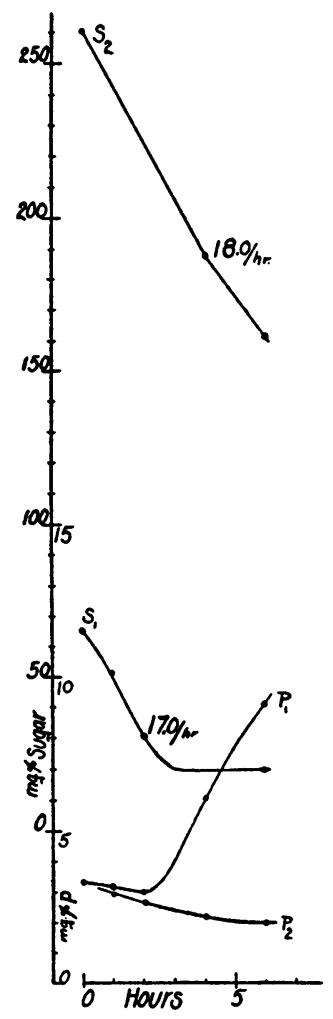

Fig. 8. Blood of a Diabetic Child Rendered Hypoglycemic by Insulin: Alone $\left(S_{1}\right.$ and $\left.P_{1}\right)$ and with Levulose Added $\left(S_{2}\right.$ and $\left.P_{2}\right)$.

The effect of added phosphate upon blood glycolysis. (Figure 9)

In the foregoing experiments are demonstrated the effects of a changed sugar concentration upon the changes of inorganic $\mathrm{P}$ in normal blood. The effect of an increased inorganic phosphate concentration upon glycolysis is displayed in Figure 9. Fifty cc. of blood were taken from a normal adult, defibrinated, and divided into two flasks. To one was added $2.0 \mathrm{cc}$. of 0.85 per cent $\mathrm{NaCl}$ solution. To the other was added $2.0 \mathrm{cc}$. of 1.2 per cent (approximate) solution of $\mathrm{Na}_{2} \mathrm{HPO}_{4} \cdot 12 \mathrm{H}_{2} \mathrm{O}$, sufficient to elevate the inorganic phosphorus content of the blood from 3.1 to $17.8 \mathrm{mgm}$. per cent. In the blood sample with the added phosphate, glycolysis occurred at a slightly faster rate $\left(\mathrm{S}_{2}\right)$ than it did in the control $\left(\mathrm{S}_{1}\right)$, and in this sample the inorganic phosphorus $\left(\mathrm{P}_{2}\right)$ was decreased more during the first 4 hours than in the control $\left(P_{1}\right)$. 


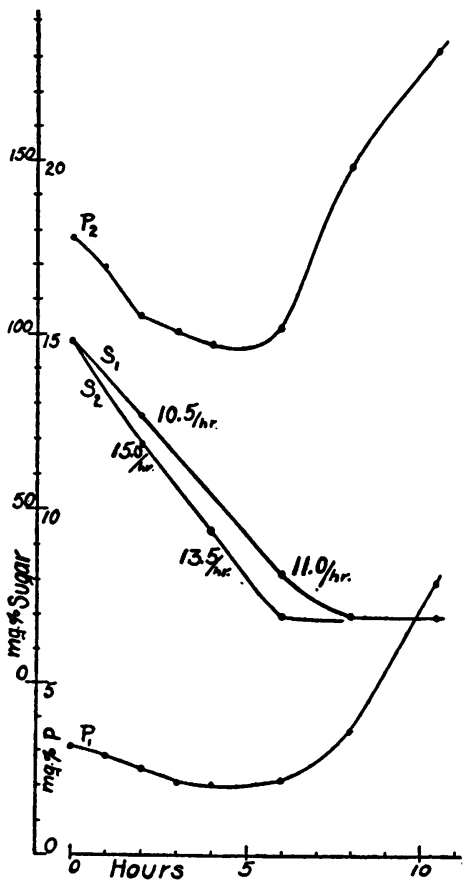

Fig. 9. Glycolysis and Changes of Inorganic Phosphorus in Normal Human Blood $\left(S_{2}\right.$ and $\left.P_{1}\right)$ and in the Same Blood with $\mathrm{Na}_{2} \mathrm{HPO}_{4}$ ADdED $\left(\mathrm{S}_{\mathbf{2}}\right.$ AND $\left.\mathrm{P}_{2}\right)$.

\section{SUMMARY}

In normal defibrinated blood incubated at $37^{\circ} \mathrm{C}$, glycolysis occurs at a fairly constant rate, usually amounting to a loss of 13 to $16 \mathrm{mgm}$. per cent per hour until there remains a residual reducing substance of about $20 \mathrm{mgm}$. per cent. During the first few hours the inorganic phosphorus of the blood either remains at a constant level or diminishes slightly. At the time the free sugar is exhausted (after 6 to 8 hours) the inorganic phosphorus rises sharply and progressively to reach a concentration of about 20 to $25 \mathrm{mgm}$. per cent at about the 15th hour. This rise of the inorganic phosphorus is at the expense of the organic acidsoluble phosphorus of the cells, generally designated "ester phosphorus." The rise occurs very quickly in the hypoglycemic blood of insulinized animals; it is delayed for several hours by the addition of an excess of levulose or dextrose to both normal and hypoglycemic blood.

\section{BIBLIOGRAPHY}

Barer, A. P., J. Clin. Invest., 1931, x, 507. A Study of Glycolysis.

Barrenscheen, H. K. and Hübner, K., Biochem. Ztschr., 1930, ccxxix, 329. Untersuchungen über die Glykolyse des Blutes. I. 
Bierry, H. and Moquet, L., Compt. rend. Soc. de Biol., 1924, xci, $250 . \quad$ Ibid., 1925, xcii, 593. Glycolyse et variations du phosphore inorganique dans le sang, in vitro.

Briggs, A. P., Koechig, I., Doisy, E. A. and Weber, C. J., J. Biol. Chem., 1923, lviii, 721. Some Changes in the Composition of Blood Due to the Injection of Insulin.

Doyon, M. and Morel, A., Compt. rend. Soc. de Biol., 1903, lv, $215 . \quad$ Rôle des éléments figurés du sang dans la glycolyse.

Engelhardt, W. A. and Braunstein, A. E., Biochem. Ztschr., 1928, cci, 48. Über die Beziehung zwischen der Phosphorsäure und der Glykolyse im Blut.

Engelhardt, W. A. and Ljubimowa, M., Biochem. Ztschr., 1930, ccxxvii, 6. Glykolyse und Phosphorsäureumsatz in den Blutzellen verschiedener Tiere.

Falcon-Lesses, M., Arch. Int. Med., 1927, xxxix, 412. Glycolysis in Normal and Leukemic Blood.

Fiske, C. H. and Subbarow, Y., J. Biol. Chem., 1925, 1xvi, 375. The Colorimetric Determination of Phosphorus.

Folin, O. and Wu, H., J. Biol. Chem., 1919, xxxviii, 81. A System of Blood Analysis.

Folin, O., J. Biol. Chem., 1926, lxvii, 357. The Determination of Sugar in Blood and in Normal Urine.

Folin, O. and Svedberg, A., J. Biol. Chem., 1926, lxx, 405. The Sugar in Urine and in Blood.

Goodwin, H. W. and Robison, R., Biochem. J., 1924, xviii, 1161. The Possible Significance of Hexosephosphoric Esters in Ossification. IV. The Phosphoric Esters of the Blood. Preliminary Communication.

Guest, G. M. and Andrus, W. DeW., J. Clin. Invest., 1932, xi, 455. Chemical Studies of the Blood in High Intestinal Obstruction, I. The Distribution of Phosphorus and Intracellular Changes.

Harden, A. and Young, W. J., Proc. Chem. Soc., 1905, xxi, 189. The Influence of Phosphates on the Fermentation of Glucose by Yeast Juice. Preliminary Communication.

Harden, A., Alcoholic Fermentation, Chapter III. The Function of Phosphates in Alcoholic Fermentation. Biochemical Monographs, Longmans, Green and Co., 1923, 3rd ed.

Harrop, G. A. and Benedict, E. M., J. Biol. Chem., 1924, lix, 683. The Participation of Inorganic Substances in Carbohydrate Metabolism.

Hiller, A., Linder, G. C. and Van Slyke, D. D., J. Biol. Chem., 1925, lxiv, 625. The Reducing Substances of the Blood.

Jost, H., Ztschr. f. physiol. Chem., 1927, clxv, 171. Utber die biologische Bedeutung des säureloslichen organischen Blutphosphors.

Katayama, I., J. Lab. and Clin. Med., 1926, xii, 239. Studies in Blood Glycolysis. General Consideration of Glycolysis in Relation to the Blood Cells, and the Production of Lactic Acid and Carbon Dioxide.

Kawashima, Y., J. Biochem., 1923, ii, 131. Über die glykolytische Kraft des Blutes. Ibid., 1924, iii, 273. II. Mitteilung.

Kay, H. D. and Byrom, F. B., Brit. J. Exp. Path., 1927, viii, 240. Blood Phosphorus in Health and Disease. I. The Distribution of Phosphorus in Human Blood in Health.

Lawaczeck, H., Biochem. Ztschr., 1924, cxlv, 351. Uber die Dynamik der Phosphorsäure des Blutes. 
Levene, P. A. and Raymond, A. L., J. Biol. Chem., 1928, lxxx, 633. Hexosediphosphate. Ibid., 1929, Ixxxi, 279. Hexosemonophosphate. (Robison.)

Löb, W., Biochem. Ztschr., 1911, xxxii, 43. Beiträge zur Frage der Glykolyse. II. Mitteilung. Die Bedeutung der Phosphate für die oxydative Glykolyse.

Mackenzie, G. M., J. Exp. Med., 1915, xxii, 757. An Experimental Study of Blood Glycolysis. The Effects of Thyroid and Adrenal Extracts and Phlorizin on Glycolysis in Vitro.

Martland, M., Biochem. J., 1925, xix, 117. The Phosphoric-Esterase of Blood at Various Hydrogen Ion Concentrations.

Martland, M., Hansman, F. S. and Robison, R., Biochem. J., 1924, xviii, 1152. The Phosphoric-Esterase of the Blood.

Milne, L. S. and Peters, H. LeB., J. Med. Res., 1912, xxi, 415. Observations on the Glycolytic Power of the Blood and Tissues in Normal and Diabetic Conditions.

Peters, J. P. and Van Slyke, D. D., Quantitative Clinical Chemistry. Chapter XX. Phosphorus. Williams and Wilkins Co., Baltimore, 1931.

Robison, R., Biochem. J., 1922, xvi, 809. A New Phosphoric Ester Produced by the Action of Yeast Juice on Hexoses.

Roche, A. and Roche, J., Compt. rend. Soc. de Biol., 1927, xcvi, 361. Sur les variations de la vitesse de la glycolyse du sang humain in vitro en fonction du $\mathrm{pH}$.

Roche, A. and Roche, J., Bull. Soc. chim. biol., 1929, xi, 549. Recherches sur la participation d'une combinaison phosphorée à la glycolyse du sang in vitro.

Rona, P. and Arnheim, F., Biochem. Ztschr., 1913, xlviii, 35. Beiträge zur Frage der Glykolyse, III.

Rona, P. and Döblin, A., Biochem. Ztschr., 1911, xxxii, 489. Beiträge zur Frage der Glykolyse, II.

Rona, P. and Iwasaki, K., Biochem. Ztschr., 1927, clxxxiv, 318. Beiträge zur Frage der Glykolyse, VII. Mitteilung. Über die Beziehung der Verteilung des Phosphors im Blute zur Glykolyse.

Wigglesworth, V. B., Woodrow, C. E., Smith, W. and Winter, L. B., J. Physiol., 1923, lvii, 447. On the Effect of Insulin on Blood Phosphate. 